\title{
HEK293 Cell Line as a Platform to Produce Recombinant Proteins and Viral Vectors
}

\author{
Evan Tan, Cara Sze Hui Chin, Zhi Feng Sherman Lim and Say Kong $\mathrm{Ng}^{*}$ \\ Bioprocessing Technology Institute, Agency for Science, Technology and Research (A*STAR), Singapore, Singapore
}

\section{OPEN ACCESS}

Edited by:

Jacinta Seraphina D'Souza, UM-DAE Centre for Excellence in

Basic Sciences, India

Reviewed by:

Somen Nandi,

University of California, Davis,

United States

Diego Cotella,

Università degli Studi del Piemonte

Orientale, Italy

*Correspondence:

Say Kong Ng

ng_say_kong@bti.a-star.edu.sg

Specialty section:

This article was submitted to

Synthetic Biology,

a section of the journal

Frontiers in Bioengineering and

Biotechnology

Received: 18 October 2021 Accepted: 25 November 2021

Published: 13 December 2021

Citation:

Tan E, Chin CSH, Lim ZFS and Ng SK (2021) HEK293 Cell Line as a Platform to Produce Recombinant Proteins and Viral Vectors.

Front. Bioeng. Biotechnol. 9:796991. doi: 10.3389/fbioe.2021.796991
Animal cell-based expression platforms enable the production of complex biomolecules such as recombinant proteins and viral vectors. Although most biotherapeutics are produced in animal cell lines, production in human cell lines is expanding. One important advantage of using human cell lines is the increased potential that the resulting biotherapeutics would carry more "human-like" post-translational modifications. Among the human cell lines, HEK293 is widely utilized due to its high transfectivity, rapid growth rate, and ability to grow in a serum-free, suspension culture. In this review, we discuss the use of HEK293 cells and its subtypes in the production of biotherapeutics. We also compare their usage against other commonly used host cell lines in each category of biotherapeutics and summarise the factors influencing the choice of host cell lines used.

Keywords: HEK293, human embryonic kidney cell 293, biotechnology, viral vectors, viral vectored vaccines, biotherapeutics and biologics

\section{INTRODUCTION}

Production of complex biopharmaceutical products rely heavily on mammalian cell lines, with most therapeutic biopharmaceuticals produced in the Chinese hamster ovary $(\mathrm{CHO})$ cells (Lalonde and Durocher, 2017). The use of mammalian production cells enables biologics with complex posttranslational modifications (PTMs) to be produced. Complex biologics such as antibodies, growth and clotting factors require complex PTMs to ensure product stability and potency. However, not all biopharmaceutical products can be produced in CHO. Some recombinant proteins are made in HEK293 due to requirements in PTMs which cannot be met in CHO, and most therapeutic viral vectors are produced in HEK293. Since 2015, there have been seven HEK-derived products approved by the FDA (Table 1). Of these, six are cell and gene therapies (Mullard, 2016, Mullard, 2017; Mullard, 2018; Mullard, 2019; Mullard, 2020; Mullard, 2021) where the HEK293 cell line or its derivatives were used in the production of viral vectors. With the increasing number of cell and gene therapies being developed (Rittié et al., 2019; Lapteva et al., 2020), we will see a corresponding growth in the use of HEK293 in viral vector production.

\section{HEK293 CELLS AND THEIR DERIVATIVES}

The HEK293 cell line was established by transforming human embryonic kidney cells with sheared adenovirus type 5 DNA (Graham et al., 1977). Since then, many subtypes and derivatives have been established, with HEK293, HEK293-T, and HEK293-F frequently used in the production of biopharmaceuticals (Yuan et al., 2018). HEK293-T is a derivative of the HEK293 cell line, 
TABLE 1 | FDA-approved biologics produced in HEK293 since 2015.

\begin{tabular}{|c|c|c|c|}
\hline Product Name & Properties & Approval & Reference \\
\hline NUWIQ ${ }^{\circledR}$ & Recombinant anti-haemophilic factor & 2015 & U.S. Food and Drug Administration (2015); Mullard, (2016) \\
\hline Voretigene neparvovec (Luxturna $\left.{ }^{\circledR}\right)$ & AAV-based RPE65 gene therapy & 2017 & U.S. Food and Drug Administration (2017a); Mullard, (2018) \\
\hline Axicabtagene cilolucel (Yescarta $\left.{ }^{\circledR}\right)$ & CD19-directed CAR T therapy & 2017 & U.S. Food and Drug Administration (2017b); Mullard, (2018) \\
\hline Tisagenlecleucel (Kymriah $\left.{ }^{\circledR}\right)$ & CD19-directed CAR T therapy & 2017 & U.S. Food and Drug Administration (2017c); Mullard, (2018) \\
\hline Onasemnogene abeparvovec (Zolgensma $\left.{ }^{\circledR}\right)$ & AAV-based SMN gene theapy & 2019 & U.S. Food and Drug Administration (2019); Mullard, (2020) \\
\hline Lisocabtagene maraleucel (Breyanzi $\left.{ }^{\circledR}\right)$ & CD19-directed CAR T therapy & 2021 & U.S. Food and Drug Administration, (2021a) \\
\hline Idecabtagene vicleucel $\left(\right.$ Abecma $\left.{ }^{\circledR}\right)$ & BCMA-directed CAR T therapy & 2021 & U.S. Food and Drug Administration, (2021b) \\
\hline
\end{tabular}

established by the expression of a temperature-sensitive SV40 T-antigen mutant (DuBridge et al., 1987). Expression of the T-antigen allows plasmids which carry the SV40 origin of replication to replicate when transfected into the cell (DuBridge et al., 1987). HEK293-F cells are GIBCO ${ }^{\circledR}$ brand cells, cloned from HEK293 and adapted to suspension culture in serum-free media.

Other notable HEK293 derivatives commonly used in recombinant protein production include HEK293-E and HEK293-6E. HEK293-E was established by the expression of Epstein-Barr nuclear antigen 1 (EBNA-1), which allows for episomal replication of plasmids with oriP. Similarly, the HEK293-6E cell line was established by the expression of a truncated EBNA-1, lacking Gly-Gly-Ala domain. HEK293-6E showed improved transient gene expression and cell growth compared to HEK293-E (Abaandou et al., 2021).

\section{RECOMBINANT PROTEIN PRODUCTION IN HEK293}

Eukaryotic expression systems are used to produce complex recombinant protein with complex PTMs for proper protein function. The use of the HEK293 host cell eliminates issues of potential immunogenicity due to the presence of non-human PTMs (Durocher and Butler, 2009). Its ease of transfectability and relatively high protein productivity makes it a popular choice for small scale production of recombinant proteins for scientific studies (Abaandou et al., 2021) and its capability to adapt to a suspension free culture facilitates its use in large scale biotherapeutics production (Baldi et al., 2005; Dumont et al., 2015).

Because of its ease of transfection, HEK293 is widely used for transient gene expression (TGE). Recombinant proteins can be produced quickly by transfecting HEK293 with readily available reagents such as calcium phosphate or polyethylenimine (PEI). Such transfection processes have been demonstrated in stirredtank bioreactors and have proved to be a good method for the rapid production of recombinant proteins for lab to pre-clinical use (Wurm and Bernard, 1999; Baldi et al., 2007). HEK293E and HEK293-6E is widely used in TGE as the use of plasmids with Epstein-Barr virus oriP significantly improves TGE (Pham et al., 2006). However, the main drawback of TGE in recombinant protein production is the need for large quantities of transfectiongrade plasmid DNA.

Stable producer cell lines are preferred for the large-scale production of recombinant proteins. The most recent
HEK-produced recombinant protein therapeutic, NUWIQ ${ }^{\circledR}$, was produced in HEK293F cells. NUWIQ ${ }^{\circledR}$ is a recombinant coagulation factor VIII (FVIII). It is produced by transfecting HEK293F cells with a B-domain deleted human FVIII expression construct. After stable transfectants were selected, clones exhibiting optimal production were selected for use (Casademunt et al., 2012; Kannicht et al., 2015).

Protein production in producer cell lines can be increased by the use of gene amplification technology (Lai et al., 2013). Use of the glutamine synthetase (GS)-mediated gene amplification and selection system has been demonstrated in HEK293 cells (Yu et al., 2018; Chin et al., 2019), and could improve recombinant protein production (Chin et al., 2019). By coupling the expression of the recombinant human erythropoietin with glutamine synthetase in a bicistronic vector, erythropoietin expression was significantly improved after the sequential increase of methionine sulfoximine, a GS inhibitor (Chin et al., 2019). Application of gene amplification technologies could expand the use of human cell lines, such as HEK293, in therapeutic recombinant protein production.

\section{Future of Recombinant Protein Production in HEK}

Host cells have a major impact on the glycosylation profile of the biotherapeutic produced (Goh and Ng, 2017). In the case of NUWIQ ${ }^{\circledR}$, HEK293-produced rFVIII exhibited improved function and reduced immunogenicity over $\mathrm{CHO}$ or $\mathrm{BHK}$ produced rFVIII as it is completely sulfated and devoid of antigenic Neu5Gc or a-Gal epitopes (Sandberg et al., 2012; Kannicht et al., 2013). HEK293 cells exhibit a greater capacity for $\gamma$-carboxylation of glutamic acid and sulfation of tyrosine residues as compared to $\mathrm{CHO}$ cells. These PTMs are required for therapeutic glycoproteins such as Drotrecogin alfa and recombinant factor IX respectively (Dumont et al., 2015). Although some biotherapeutics are still produced in human cell lines such as HEK293 due to specific PTM requirements, most complex recombinant glycoproteins are produced in $\mathrm{CHO}$.

Amongst the mammalian expression platforms available in the biopharmaceutical industry, Chinese hamster ovary $(\mathrm{CHO})$ cells are used to produce approximately $70 \%$ of recombinant biologics, especially monoclonal antibodies (Lalonde and Durocher, 2017). CHO cells are widely used due to their high productivity, ability to be cultured in suspension, in a serum-free, chemically defined cell culture media. In addition, recombinant proteins produced in $\mathrm{CHO}$ carry human-like PTMs which 
improves bioactivity and reduces immunogenicity due to the absence of an a-galactose epitope (Lai et al., 2013).

Compared to $\mathrm{HEK}, \mathrm{CHO}$ cells are not able to completely reproduce human glycostructures. This is because $\mathrm{CHO}$ cells do not express the enzymes $\beta$-galactoside $\alpha 2,6$-sialyltransferase, $\alpha 1,3 / 4$ fucosyl transferase or $\beta-1,4-\mathrm{N}$ acetylglucosaminyltransferase III, which are expressed in human cell lines (Goh and $\mathrm{Ng}$, 2017). In addition, as they express cytidine monophosphate $\mathrm{N}$-acetylneuraminic acid hydroxylase, glycoproteins produced in $\mathrm{CHO}$ carry the potentially immunogenic N-glycolylneuraminic acid (Tejwani et al., 2018). As glycoproteins with desirable glycosylation profiles can exhibit higher potency, stability, half-life and reduced immunogenicity (Tejwani et al., 2018), the advantage of HEK293 as a host cell line lies in the specific glycosylation profile requirement of the biotherapeutic product produced. This limitation in $\mathrm{CHO}$ can potentially be overcome by engineering cells capable of producing glycoproteins with desired glycosylation profiles (Tejwani et al., 2018; Nguyen et al., 2021). Required and desirable glycosylation profiles can be engineered by the expression of enzymes found in humans (Nguyen et al., 2021), or the knockout of enzymes absent in humans (Chai et al., 2020). With these developments in CHO cell glycoengineering, we foresee a further decline in the use of HEK293 as host cells for therapeutic recombinant protein production.

\section{VIRAL VECTOR PRODUCTION IN HEK293}

HEK293 is commonly used in the production of viral vectors. It is used in the production of adenoviral and adeno-associated viral vectors due to presence of the adenoviral E1A/B genes which provide helper functions during viral vector production. In retroviral vector production, HEK293T is used due to the expression of the SV40 large T-antigen in the cell line. Expression of the T-antigen allows plasmids which carry the SV40 origin of replication to undergo replication when transfected into the cell (DuBridge et al., 1987). It was also reported that expression of the large $\mathrm{T}$-antigen improved lentiviral vector production (Gama-Norton et al., 2011). However, the improved viral titers in HEK293T were not completely attributed to the effect of T-antigen on plasmid replication or transcriptional activity, suggesting that there are other indirect effects and characteristics of the cell line which enables high-titer retroviral vector production (Gama-Norton et al., 2011; Bae et al., 2020).

Early viral vector production was challenging as production was performed by the transient transfection of adherent HEK293 cells in serum-containing media. Recent advancements in transient transfection technologies, cell line and media development have demonstrated that viral vector production can be performed using serum-free suspension-based transfection process in chemically defined cell culture medium. In addition, stable viral vector producer cell lines have been established. Together, these developments have enabled the scalable production of viral vectors in HEK293 cells.

\section{Current Technologies for Retroviral Vector Production}

Retroviral vectors are enveloped, single-stranded RNA viruses. In this family of viruses, $\gamma$-retroviruses $(\gamma \mathrm{RV})$ based on the Murine Leukemia Virus and lentiviruses (LV) based on the Human Immunodeficiency Virus type 1, are commonly used in gene therapies (Elsner and Bohne, 2017; Milone and O'Doherty, 2018). These retroviruses are broadly classified according to their genome organisation into "simple" and "complex" retroviruses respectively (Weiss, 1996). Simple retroviruses contain two separate populations of viral RNAs, where viral genomic RNA is distinct from mRNA. In complex retroviruses, viral genomic RNA functions as mRNA (Balvay et al., 2007).

Retroviral vectors are one of the best tools for gene transfer due to its ability to transduce wide range of cell types (Ausubel et al., 2012). Retroviral transduction can stably modify transduced cells as the retroviral RNA genome, which is converted to DNA by the retroviral reverse transcriptase, can be stably integrated into the host cell's genome. As LV vectors exhibit a less harmful integration profile compared to $\gamma \mathrm{RV}$ vectors, they are more widely used in gene therapies (Mitchell et al., 2004; Elsner and Bohne, 2017). Both $\gamma$ RVs and LVs have been used in the production of chimeric antigen receptor (CAR) T-cell therapies (Milone and O'Doherty, 2018). Since 2017, there have been four FDA approved CAR-T therapies, Yescarta, Kymriah, Breyanzi, and Abecma.

For both $\gamma \mathrm{RV}$ and LV vector production, different packaging systems have been developed with each successive generation developed aimed at reducing the risk for replication competent viruses (RCV). In $\gamma \mathrm{RV}$ production, as the viral genes are noncytotoxic, packaging cell lines have been developed to facilitate $\gamma \mathrm{RV}$ production. In third generation $\gamma \mathrm{RV}$ packaging cell lines, gag-pro-pol genes, and the envelope protein are stably expressed in separate expression casettes. $\gamma \mathrm{RV}$ production is then achieved by transfection of the packaging cell line with a single vector construct carrying the transgene-of-interest, the $\Psi$ packaging signal, and a modified long terminal repeat (LTR) species to further minimize risk of RCV formation (Rodrigues et al., 2011).

Cytotoxicity of LV genes has made it challenging to establish packaging or producer cell lines. Hence, a four-plasmid transient transfection workflow is widely utilised in the production of LV vectors (Ausubel et al., 2012). The plasmids carry: 1) Gag-Pro-Pol which encodes viral structural proteins and enzymes; 2) Rev which expresses accessory proteins that is essential for viral genome nuclear exportation; 3) Env that encodes for the envelope glycoproteins which engage with cell receptors for cellular entry and; 4) Vector genome that carries the gene of interest (Tomás et al., 2018).

Retroviral vectors are typically produced by the transient transfection of adherent HEK293T cells (Loo et al., 2012; Bauler et al., 2020). However, scaling up production from monolayer flasks is time consuming, labour intensive and requires large workspaces for cell cultivation (Rout-Pitt et al., 2018). To improve process scalability, several serum-free suspension-based production methods have been developed (Segura et al., 2007; Ansorge et al., 2009; Bauler et al., 2020). 
TABLE 2 | Comparison of various $\gamma \mathrm{RV}$ production methods.

\begin{tabular}{|c|c|c|c|c|}
\hline Reference & Ghani et al. (2007) & Loew et al. (2010) & Loo et al. (2012) & Ghani et al. (2019) \\
\hline Production type & Transient, Packaging cell line & $\begin{array}{l}\text { Packaging cell line for stable } \\
\text { production }\end{array}$ & Transient & Stable \\
\hline Culture format & Suspension & Adherent & Adherent & $\begin{array}{l}\text { Adherent. Parental cell line can be } \\
\text { suspension adapted Ghani et al. } \\
\text { (2007) }\end{array}$ \\
\hline $\begin{array}{l}\text { Cell culture media } \\
\text { used }\end{array}$ & $\begin{array}{l}\text { H-SFM derived medium with } 0.1 \% \text { lipid } \\
\text { mixture, } 0.1 \% \text { bovine serum albumin, } 0.1 \% \\
\text { Pluronic F68 }\end{array}$ & $\begin{array}{l}\text { DMEM }+10 \% \text { heat inacitvated } \\
\text { Fetal calf serum }\end{array}$ & DMEM $+10 \%$ FBS & $\mathrm{DMEM}+10 \%$ FBS \\
\hline Cells & 293SF & HEK293T & HEK293T & 293Vec \\
\hline $\begin{array}{l}\text { Transfection } \\
\text { method }\end{array}$ & Calcium phosphate & $\begin{array}{l}\text { Lipofection, Translt293 } \\
\text { reagent }\end{array}$ & Calcium phosphate & NA \\
\hline Titer & $4 \mathrm{E} 7 \mathrm{IU} / \mathrm{ml}$ & 1E6 IP/mL & 1.5E7 $\mathrm{IU} / \mathrm{ml}$ & 2E7 IU/ml for 3 months \\
\hline Titration method & $\begin{array}{l}\text { GFP expression of transduced HT-1080 } \\
\text { cells by flow cytometry }\end{array}$ & $\begin{array}{l}\text { GFP expression of transduced } \\
\text { HT- } 1080 \text { cells by flow } \\
\text { cytometry }\end{array}$ & $\begin{array}{l}\text { GFP expression of transduced } \\
\text { HT-1080 or NIH3T3 cells by flow } \\
\text { cytometry }\end{array}$ & $\begin{array}{l}\text { GFP expression of transduced } \\
\text { HT-1080 cells by flow cytometry }\end{array}$ \\
\hline $\begin{array}{l}\text { Production scale } \\
\text { tested }\end{array}$ & Shake flasks & T-Flasks & Wave cell bag with Fibra-Cel disks & $10 \mathrm{~cm}$ cell culture dishes \\
\hline Type of vector & SIN $\gamma$-retroviral vectors & SIN $\gamma$-retroviral vectors & SIN $\gamma$-retroviral vectors & SIN $\gamma$-retroviral vectors \\
\hline $\begin{array}{l}\text { Envelope protein/ } \\
\text { Pseudotype }\end{array}$ & Amphotropic envelope & GALV & GALV and RD114 & RD114 \\
\hline
\end{tabular}

\begin{tabular}{|c|c|c|c|c|c|c|c|}
\hline Reference & \multicolumn{2}{|c|}{ Bauler et al. (2020) } & $\begin{array}{l}\text { Rout-Pitt et al. } \\
\qquad(2018)\end{array}$ & $\begin{array}{l}\text { Ausubel et al. } \\
\qquad(2012)\end{array}$ & $\begin{array}{l}\text { Segura et al. } \\
\qquad(2007)\end{array}$ & $\begin{array}{l}\text { Tomás et al. } \\
\text { (2018) }\end{array}$ & $\begin{array}{l}\text { Chen at } \\
\text { al., (2020) }\end{array}$ \\
\hline $\begin{array}{l}\text { Production } \\
\text { type }\end{array}$ & Transient & Transient & Transient & Transient & Transient & Stable constititive & Stable inducible \\
\hline Culture format & Adherent & Suspension & Adherent & Adherent & Suspension & Adherent & Suspension \\
\hline $\begin{array}{l}\text { Cell culture } \\
\text { media used }\end{array}$ & $\begin{array}{l}\text { DMEM +10\% } \\
\text { FBS }+2 \mathrm{mM} \\
\text { L-alanyl-L } \\
\text { glutamine }\end{array}$ & Freestyle 293 & $\begin{array}{l}\text { DMEM, 10\% FCS, } \\
10 \text { units/ml Penicillin, } \\
10 \mu \mathrm{g} / \mathrm{ml} \\
\text { Streptomycin }\end{array}$ & $\begin{array}{l}\text { DMEM supplemented } \\
\text { with } 10 \% \text { FBS, } 1 \% \\
\text { sodium pyruvate, and } \\
1 \% \text { glutamine }\end{array}$ & Freestyle & DMEM w/10\% FBS & $\begin{array}{l}\text { Unspecified } \\
\text { 'Serum-Free } \\
\text { culture medium' }\end{array}$ \\
\hline Cells & HEK293T & HEK293T & HEK293T & HEK293T & HEK293E-6E & HEK293T & HEK293T \\
\hline $\begin{array}{l}\text { Transfection } \\
\text { method }\end{array}$ & PElpro & PElpro & Calcium phosphate & Calcium phosphate & 25-kDa Linear PEI & N.A & N.A. \\
\hline Titer & 1.5E8 TU/mL & 8.2E7 TU/mL & 1E8-1E9 TU/mL & 5E7-3E8 TU/mL & 1E6 IU/ml & $\begin{array}{l}\text { 1E6 TU/mL/Day, } \\
\text { Stable for } \\
>2 \text { months }\end{array}$ & $\begin{array}{l}\text { 1E7 TU/mL, } \\
\text { Stable for } \\
\sim 2 \text { weeks }\end{array}$ \\
\hline $\begin{array}{l}\text { Titration } \\
\text { method }\end{array}$ & $\begin{array}{l}\text { ddPCR of } \\
\text { transduced HOS } \\
\text { cells }\end{array}$ & $\begin{array}{l}\text { ddPCR of } \\
\text { transduced } \\
\text { HOS cells }\end{array}$ & RT-PCR & $\begin{array}{l}\text { GFP expression of } \\
\text { transduced HT-1080 } \\
\text { cells was measured by } \\
\text { flow cytometry }\end{array}$ & $\begin{array}{l}\text { GFP expression of } \\
\text { transduced } \\
\text { HEK293E-6E cells } \\
\text { by flow cytometry }\end{array}$ & $\begin{array}{l}\text { GFP fluorescence } \\
\text { by flow cytometry of } \\
\text { transduced } \\
\text { HEK293T }\end{array}$ & $\begin{array}{l}\text { qPCR of } \\
\text { transduced } \\
\text { A3.01 cells }\end{array}$ \\
\hline $\begin{array}{l}\text { Production } \\
\text { scale }\end{array}$ & Cell factory & $\begin{array}{l}\text { 5L Erlenmeyer } \\
\text { shake flask }\end{array}$ & Cell factory & $\begin{array}{l}\text { CellSTACK - } 10 \\
\text { Chamber }\end{array}$ & 3L STB & Tissue culture flasks & $\begin{array}{l}\text { 2L Erlenmeyer } \\
\text { flasks }\end{array}$ \\
\hline Type of vector & $\begin{array}{l}\text { Third-generation } \\
\text { lentiviral vector }\end{array}$ & $\begin{array}{l}\text { Third- } \\
\text { generation } \\
\text { lentiviral vector }\end{array}$ & $\begin{array}{l}\text { Second-generation } \\
\text { lentiviral vector }\end{array}$ & $\begin{array}{l}\text { Third-generation } \\
\text { lentiviral vector }\end{array}$ & $\begin{array}{l}\text { Third-generation } \\
\text { lentiviral vector }\end{array}$ & $\begin{array}{l}\text { Third-generation } \\
\text { lentiviral vector }\end{array}$ & $\begin{array}{l}\text { Third-generation } \\
\text { lentiviral vector }\end{array}$ \\
\hline $\begin{array}{l}\text { Envelope } \\
\text { protein/ } \\
\text { Pseudotype }\end{array}$ & VSV-G & VSV-G & VSV-G & VSV-G & VSV-G & 4070A & VSV-G \\
\hline
\end{tabular}

The suspension-based production methods demonstrated comparable volumetric productivities compared to adherentbased production methods (Table 2 and 3). Despite the improvement in process scalability, retroviral vector production remains challenging. There are high costs incurred for good quality transfection-grade DNA and reagents involved (Merten et al., 2016). In addition, the batch-to-batch variability and short production periods has led to the limitation in production of high-titer and consistent viral vectors (McCarron et al., 2016). 


\section{Future of Retroviral Vector Production}

Stable producer cell lines have been generated to improve the scalability of $\gamma \mathrm{RV}$ and LV production. Stable, suspension-adapted producer cell lines developed from packaging cell lines could produce yRVs in a serum-free medium have been developed to improve process scalability (Ghani et al., 2007). Subsequently, yRVs producer cell lines for the safer, self-inactivating (SIN) yRVs have also been developed (Loew et al., 2010; Ghani et al., 2019). SIN vectors were first developed by the modification of the U3 sequences of the 3 viral LTR, resulting in the loss of viral enhancer and promoter sequences upon integration in the transduced cell (Yu et al., 1986) This reduces the risk of RCV formation as the viral promoter and enhancers are absent, thus preventing vector mobilisation. In addition, when coupled with the use of weak internal promoters to drive the expression of the gene of interest, risk genotoxicity could be reduced (Modlich et al., 2006; Maetzig et al., 2011).

Stable LV producer cell line are challenging to develop due to the cytotoxicity of the genes required. This can be overcome by using less-cytotoxic viral protease mutants or envelope proteins (Tomás et al., 2018) or the use of inducible expression systems (Stewart et al., 2009; Manceur et al., 2017; Chen et al., 2020). The LentiPro26 stable lentiviral vector producer cell lines was developed by Tomás et al., demonstrated stable, constitutive LV production over a period of up to 2 months while maintaining a volumetric titer comparable to existing transient-transfection based production methods (Tomás et al., 2018). Chen et al., demonstrated that stable producer cell lines can be rapidly generated by the transfection of a single DNA construct carrying all required lentiviral vector components, cutting down the time taken to generate and identify stable producing clones form 6 months in the LentiPro26 system (Tomás et al., 2018), to approximately 4 months (Chen et al., 2020). Further developments in stable $\gamma \mathrm{RV}$ and LV production systems would improve $\gamma \mathrm{RV}$ and $\mathrm{LV}$ productivities to meet the growing demand of these vectors in clinical gene therapy applications.

\section{Current Technologies for Adeno-Associated Virus Production in HEK} Adeno-associated viruses (AAV) are non-enveloped, singlestranded DNA viruses which have shown safety and efficacy as gene therapy vectors (Naso et al., 2017). Since 2012, there have been three approved rAAV gene therapies, namely Glybera, Luxturna, and, most recently, Zolgensma.

Recombinant AAVs (rAAVs) are typically produced via the transient-transfection of adherent HEK293 cells with three plasmids containing: 1) Adenoviral helper factors, E4, E2a, and VARNA; 2) Adeno-associated virus rep and cap genes; and 3) Cargo gene flanked by AAV ITR sequences (Naso et al., 2017). HEK293 cells are most frequently used for rAAV production due to the expression of adenoviral Ela/b genes (Graham et al., 1977) which are essential for AAV production (Richardson and Westphal, 1984). Although the HeLa cell line was used for rAAV production in early studies (Tratschin et al., 1984), HEK293 based cell lines are typically favored due to the expression of the adenoviral viral helper genes, E1A/B, which improves rAAV titers during production.

\section{Helper-Virus Based rAAV Production/HSV Production System in HEK293}

rAAVs can also be produced with the use of helper viruses (Clark, 2002). Wild-type AAVs require co-infection with adenoviruses to undergo productive infection. Early rAAV production used a helper-virus production system whereby, rAAV production is achieved by the infection of host cells with recombinant helper viruses carrying the AAV rep, cap, and cargo genes (Clark, 2002). Typically, two recombinant viruses are used, one carrying the rep and cap genes, and another carrying the cargo genes. This minimizes recombination, thus reducing the risk of wild-type AAV formation (Clark, 2002). The use of helper-virus based rAAV production systems are not favoured due to the need to separate the helper-virus from the rAAVs during purification, and the need to demonstrate the absence of replication-competent viruses from the purified.

\section{Future of rAAV Production Technologies in HEK293}

Although the production of rAAVs for the above therapeutics were performed in adherent-based systems, suspension-based rAAV production technologies have been also developed recently. rAAV production have been demonstrated in suspension adapted HEK293 cell lines with yields comparable to existing adherent-based production systems (Table 4) (Lock et al., 2010; Chahal et al., 2014; Grieger et al., 2016; Blessing et al., 2018; Strobel et al., 2019). With a growing number of suspensionbased methods used for the production of rAAV therapeutics in clinical trials (Clément and Grieger, 2016), we forsee the shift away from adherent-based production methods in favor of the more scalable, suspension-based production methods.

Stable producer cell lines have also been developed to improve the scalability of rAAV production. CEVEC pharmaceuticals have developed ELEVECTA ${ }^{\circledR}$ producer cell lines where AAV production genes are stably expressed in CEVEC's amniocyte production (CAP) cells where gene expression is controlled by an inducible promoter. Scalable rAAV production is achieved simply by induction, without the use of helper viruses, transfection reagents or plasmids (CEVEC, 2020).

While rAAVs are commonly produced in HEK293-based systems, baculovirus-based systems have been developed showing comparable rAAV titers. The use of the baculovirus expression vector system for $\mathrm{rAAV}$ production was first described in 2002 (Urabe et al., 2002) where rAAV production was achieved with the co-infection of Spodoptera frugiperda (Sf9) cells with three recombinant baculoviruses, a Rep-baculovirus, a Capbaculovirus, and a Cargo ITR baculovirus, with the helper functions provided for by the baculovirus.

The OneBac rAAV production systems were developed to improve the scalability of the production system by reducing the number of required recombinant baculoviruses for production from three to one. This was achieved by generating Sf9 cell lines stably expressing the AAV rep and cap genes (Mietzsch et al. 2014, 2015, 2017). This resulted in a more scalable production 
TABLE 4 | Comparison of various rAAV production methods.

\begin{tabular}{|c|c|c|c|c|c|}
\hline Reference & $\begin{array}{l}\text { Strobel et al. } \\
\qquad(2019)\end{array}$ & $\begin{array}{l}\text { Blessing et al. } \\
\text { (2018) }\end{array}$ & $\begin{array}{l}\text { Grieger et al. } \\
\qquad(2016)\end{array}$ & $\begin{array}{l}\text { Chahal et al. } \\
\qquad(2014)\end{array}$ & $\begin{array}{l}\text { Lock et al. } \\
\qquad(2010)\end{array}$ \\
\hline Culture format & Adherent & Suspension & Suspension & Suspension & Adherent \\
\hline Cell culture media used & DMEM +5\%FBS & $\mathrm{F} 17$ & F17, CDM4HEK293 & SFM4Transfx-293 Medium & DMEM + 10\% FBS \\
\hline Cells & HEK293 & HEKExpress & HEK293 & HEK293SF-3F6 & HEK293 \\
\hline Transfection method & Calcium phosphate & 25-kDa Linear PEl & PEI Max & 25-kDa Linear PEl & PEI Max \\
\hline Production scale & Cell Disc & TubeSpin 600 & 20L WAVE Bioreactor & 3L STB & CellSTACK - 10 Chamber \\
\hline Titer & AAV2: $1.2-4 \times 10^{13} / \mathrm{vg} / \mathrm{L}$ & $\begin{array}{l}\text { AAV8: } 2.1 \times 10^{11} / \mathrm{L} \\
\text { AAV9: } 3 \times 10^{11} / \mathrm{L}\end{array}$ & AAV2: $2.3 \times 10^{13} / \mathrm{L}$ & $\begin{array}{l}\text { AAV2: } 2.1 \times 10^{13} / \mathrm{L} \\
\text { AAV6: } 2 \times 10^{12} / \mathrm{L}\end{array}$ & $\begin{array}{l}\text { AAV7: } 2.5 \times 10^{13} / \mathrm{L} \\
\text { AAV6: } 1.2 \times 10^{12} / \mathrm{L} \\
\text { AAV8: } 1.38 \times 10^{14} / \mathrm{L}\end{array}$ \\
\hline qPCR titering region & CMV & ITR & GFP & CMV & PolyA \\
\hline
\end{tabular}

system with improved titers over HEK293-based systems. Although the systems described demonstrated similar functionality between Sf9-produced and HEK293-produced rAAVs, a recent study identified the differences between rAAVs produced in both systems (Rumachik et al., 2020). The rAAV capsids produced in Sf9 cells had different post translational modifications compared to those produced in HEK293 (Rumachik et al., 2020). Genomes of rAAVs produced in HEK293 cells exhibited methylation patterns indicative of increased vector potency (Rumachik et al., 2020). Although only serotypes AAV1 and AAV8 were tested, this suggests that HEK293-produced rAAVs are preferred due to the improved vector potency. Unless future serotypes assessed demonstrates that Sf9-produced rAAVs could have improved vector potency, rAAV production in HEK293 would be preferred.

\section{Production of Adenoviral-Vectored Vaccines and Oncolytic Adenoviruses}

Adenoviruses (AdV) are non-enveloped, double-stranded DNA viruses. It was first used as a gene therapy vector as they possess high genomic capacity, high transduction efficiency and were non-integrating with high epichromosomal persistence (Bulcha et al., 2021). However, their applicability is limited in gene therapies limited due to a fatal systemic inflammatory response following AdV gene transfer (Raper et al., 2003). Although the use of AdVs in gene therapies have declined due to this unfortunate incident, AdVs have seen a resurgent use in applications where an immunological response is desired. The capacity to induce a strong immune response has led to the development of vaccine candidates for infectious diseases and cancer immunotherapies (Mendonça et al., 2021). AdVs now constitute majority of viral vectors in clinical trials with its predominant application as vaccines or in cancer therapies (Bulcha et al., 2021).

The COVID-19 pandemic drove the rapid development of adenoviral vectored vaccines and their eventual emergency use (Mendonça et al., 2021). Of the three adenoviral vectored vaccines approved for emergency use by the World Health Organisation (as of August 2021), Ad5-nCOV(Zhu et al., 2020) and ChAdOX1-nCoV (Doremalen et al., 2020) are produced in HEK293 cells, while Ad26. COV2-S is produced in PER. C6 cells (Bos et al., 2020). These cells are utilised to produce of $\mathrm{AdV}$ vectors due to the need for transcomplementation of viral vector genes in the production cell lines.

First generation AdV vectors are produced by the substitution of the E1 and/or E3 regions with an expression cassette. E1 gene products which are necessary for viral production, are provided for in trans in production cell lines such as HEK293 or PER. C6. Products from the E3 gene region are not essential for viral replication and hence, does not need to be complemented. Due to the expression of other viral proteins, first-generation adenoviral vectors provoke an immune response. In the case of a vaccine, the immune response elicited is particularly advantageous (Danthinne and Imperiale, 2000).

Subsequent generation of $\mathrm{AdV}$ vectors involve the removal of viral genes to minimize the immune response elicited from the use of these vectors in vivo. In second generation AdV vectors, additional genes required for viral replication have been inactivated. Virus production is performed in cell lines expressing the E2 and/or E4 gene products. Finally, in the third class of "gutless adenovirus", all viral genes have been removed except for the cis-acting DNA sequences required for viral DNA replication and packaging (Danthinne and Imperiale, 2000). Advancements to these AdV production systems involve modifications to reduce sequence homology and thus, reducing the risk of generating wild-type $\mathrm{AdV}$ through random recombination events (Tripodi et al., 2021) or modifications to minimize transgene expression during viral propagation to improve viral production (Danthinne and Imperiale, 2000; Tripodi et al., 2021).

\section{Other Production Systems for Adeno-Associated Viruses and Adenoviruses}

Production of AdVs and AAVs require the transcomplementation of the adenoviral E1 genes in HEK293 cells. However, as HEK293 cells were generated using sheared AdV genomic DNA, the E1 gene carried DNA sequences with high homology to wild-type AdVs. Production of first-generation E1deleted adenoviral vectors in HEK293 cells resulted in the generation of RCV with E1 sequences regained, presumably resulting from homologous recombination (Hehir et al., 1996). Despite the use of E1 and E3 deleted adenoviral vectors, 
formation of RCVs could not be eliminated (Lochmller et al., 1994).

To reduce homology, using a defined E1 gene region to transform a cell line would reduce the risk of generating wildtype AdV through random recombination events during AdV production. The PER. C6 cell line was established by the transfection of human embryonic retinal cells with a defined region of the Adenovirus type $5 \mathrm{E} 1$ gene under the control of the human phosphoglycerate kinase promoter (Fallaux et al., 1998). Production of E1-deleted adenoviral vectors in the PER. C6 cells did not result in the generation of replication competent viruses, allowing for the cost-effect production of AdV vectors. Akin to PER. C6 cells, CEVEC's CAP cells were immortalized with a vector containing E1 and pIX of AdV 5, for the purpose of high titer production of replication-deficient adenoviral vectors without the accidental formation of RCVs (Schiedner et al., 2000). AdV production might be preferred in these cell lines over HEK293 due to the decreased risk of accidental RCV formation.

\section{CONCLUSION}

The human cell line, HEK293, have emerged to be the main production platform for therapeutic viral vectors. Advancements in cell line developments would see more HEK293 clones or derivatives developed for growth in a serum-free suspension medium for high-titer viral vector production. Current examples include the commercially available $\mathrm{LV}$ and $\mathrm{AAV}$

\section{REFERENCES}

Abaandou, L., Quan, D., and Shiloach, J. (2021). Affecting HEK293 Cell Growth and Production Performance by Modifying the Expression of Specific Genes. Cells 10, 1667. doi:10.3390/cells 10071667

Ansorge, S., Lanthier, S., Transfiguracion, J., Durocher, Y., Henry, O., and Kamen, A. (2009). Development of a Scalable Process for High-Yield Lentiviral Vector Production by Transient Transfection of HEK293 Suspension Cultures. J. Gene Med. 11, 868-876. doi:10.1002/jgm.1370

Ausubel, L. J., Hall, C., Sharma, A., Shakeley, R., Lopez, P., Quezada, V., et al. (2012). Production of CGMP-Grade Lentiviral Vectors. Bioproc. Int 10, 32-43.

Bae, D. H., Marino, M., Iaffaldano, B., Fenstermaker, S., Afione, S., Argaw, T., et al. (2020). Design and Testing of Vector-Producing HEK293T Cells Bearing a Genomic Deletion of the SV40 T Antigen Coding Region. Mol. Ther. - Methods Clin. Dev. 18, 631-638. doi:10.1016/j.omtm.2020.07.006

Baldi, L., Hacker, D. L., Adam, M., and Wurm, F. M. (2007). Recombinant Protein Production by Large-Scale Transient Gene Expression in Mammalian Cells: State of the Art and Future Perspectives. Biotechnol. Lett. 29, 677-684. doi:10.1007/s10529-006-9297-y

Baldi, L., Muller, N., Picasso, S., Jacquet, R., Girard, P., Thanh, H. P., et al. (2005). Transient Gene Expression in Suspension HEK-293 Cells: Application to LargeScale Protein Production. Biotechnol. Prog. 21, 148-153. doi:10.1021/bp049830x

Balvay, L., Lastra, M. L., Sargueil, B., Darlix, J.-L., and Ohlmann, T. (2007). Translational Control of Retroviruses. Nat. Rev. Microbiol. 5, 128-140. doi:10.1038/nrmicro1599

Bauler, M., Roberts, J. K., Wu, C.-C., Fan, B., Ferrara, F., Yip, B. H., et al. (2020). Production of Lentiviral Vectors Using Suspension Cells Grown in Serum-free Media. Mol. Ther. - Methods Clin. Dev. 17, 58-68. doi:10.1016/j.omtm.2019.11.011

Blessing, D., Vachey, G., Pythoud, C., Rey, M., Padrun, V., Wurm, F. M., et al. (2019). Scalable Production of Aav Vectors in Orbitally Shaken Hek293 Cells. Mol. Ther. - Methods Clin. Dev. 13, 14-26. doi:10.1016/j.omtm.2018.11.004 vector production workflow offered by Thermo Fisher Scientific, where their HEK293-derived Viral Production Cells (VPC) are used in the LV-MAX ${ }^{\mathrm{TM}}$ system and the upcoming VPC 2.0 used in their prototype AAV-MAX system.

Future of viral vector production technologies leans towards development of stable cell lines for AAV, LV and yRV production. Such processes enable the production of viral vectors without the need to use costly reagents required for transfection. In stable producer cell lines, process developments in $\mathrm{CHO}$ resulted in a 10-20 fold improvement in glycoprotein production (Hacker et al., 2009; Kunert and Reinhart, 2016). Advancements in HEK293 cell culture media development and process technologies could lead to a similar improvement of viral vector production in stable production systems.

\section{AUTHOR CONTRIBUTIONS}

SKN initiated the manuscript. SKN, ET, CC, ZFL contributed to writing the manuscript. All authors read and approved the final manuscript.

\section{FUNDING}

This review is supported by the Agency for Science, Technology and Research (A*STAR), grant numbers H1701a0012 and I21D1AG026.

Bos, R., Rutten, L., van der Lubbe, J. E. M., Bakkers, M. J. G., Hardenberg, G., Wegmann, F., et al. (2020). Ad26 Vector-Based COVID-19 Vaccine Encoding a Prefusion-Stabilized SARS-CoV-2 Spike Immunogen Induces Potent Humoral and Cellular Immune Responses. Npj Vaccin. 5, 91. doi:10.1038/s41541-02000243-x

Bulcha, J. T., Wang, Y., Ma, H., Tai, P. W. L., and Gao, G. (2021). Viral Vector Platforms within the Gene Therapy Landscape. Sig Transduct Target. Ther. 6, 53. doi:10.1038/s41392-021-00487-6

Casademunt, E., Martinelle, K., Jernberg, M., Winge, S., Tiemeyer, M., Biesert, L., et al. (2012). The First Recombinant Human Coagulation Factor VIII of Human Origin: Human Cell Line and Manufacturing Characteristics. Eur. J. Haematol. 89, 165-176. doi:10.1111/j.1600-0609.2012.01804.x

CEVEC (2020). Stable AAV Production. Available at: https://cevec.com/ applications/aav/(Accessed September 9, 2021).

Chahal, P. S., Schulze, E., Tran, R., Montes, J., and Kamen, A. A. (2014). Production of Adeno-Associated Virus (AAV) Serotypes by Transient Transfection of HEK293 Cell Suspension Cultures for Gene Delivery. J. Virol. Methods 196 163-173. doi:10.1016/j.jviromet.2013.10.038

Chai, Y.-R., Cao, X.-X., Ge, M.-M., Mi, C.-L., Guo, X., and Wang, T.-Y. (2020). Knockout of Cytidine Monophosphate-N-Acetylneuraminic Acid Hydroxylase in Chinese Hamster Ovary Cells by CRISPR/Cas9-based Gene-Editing Technology. Biochem. Eng. J. 161, 107663. doi:10.1016/j.bej.2020.107663

Chen, Y. H., Pallant, C., Sampson, C. J., Boiti, A., Johnson, S., Brazauskas, P., et al. (2020). Rapid Lentiviral Vector Producer Cell Line Generation Using a Single DNA Construct. Mol. Ther. - Methods Clin. Dev. 19, 47-57. doi:10.1016/ j.omtm.2020.08.011

Chin, C. L., Goh, J. B., Srinivasan, H., Liu, K. I., Gowher, A., Shanmugam, R., et al. (2019). A Human Expression System Based on HEK293 for the Stable Production of Recombinant Erythropoietin. Sci. Rep. 9, 16768. doi:10.1038/s41598-019-53391-Z

Clark, K. R. (2002). Recent Advances in Recombinant Adeno-Associated Virus Vector Production. Kidney Int. 61, S9-S15. doi:10.1046/j.15231755.2002.0610s1009.x 
Clément, N., and Grieger, J. C. (2016). Manufacturing of Recombinant AdenoAssociated Viral Vectors for Clinical Trials. Mol. Ther. - Methods Clin. Dev. 3, 16002. doi:10.1038/mtm.2016.2

Danthinne, X., and Imperiale, M. J. (2000). Production of First Generation Adenovirus Vectors: a Review. Gene Ther. 7, 1707-1714. doi:10.1038/ sj.gt. 3301301

DuBridge, R. B., Tang, P., Hsia, H. C., Leong, P. M., Miller, J. H., and Calos, M. P. (1987). Analysis of Mutation in Human Cells by Using an Epstein-Barr Virus Shuttle System. Mol. Cel. Biol. 7, 379-387. doi:10.1128/mcb.7.1.379

Dumont, J., Euwart, D., Mei, B., Estes, S., and Kshirsagar, R. (2015). Human Cell Lines for Biopharmaceutical Manufacturing: History, Status, and Future Perspectives. Crit. Rev. Biotechnol. 36, 1110-1122. doi:10.3109/ 07388551.2015.1084266

Durocher, Y., and Butler, M. (2009). Expression Systems for Therapeutic Glycoprotein Production. Curr. Opin. Biotechnol. 20, 700-707. doi:10.1016/ j.copbio.2009.10.008

Elsner, C., and Bohne, J. (2017). The Retroviral Vector Family: Something for Everyone. Virus Genes 53, 714-722. doi:10.1007/s11262-017-1489-0

Fallaux, F. J., Bout, A., van der Velde, I., van den Wollenberg, D. J. M., Hehir, K. M., Keegan, J., et al. (1998). New Helper Cells and Matched Early Region 1-Deleted Adenovirus Vectors Prevent Generation of Replication-Competent Adenoviruses. Hum. Gene Ther. 9, 1909-1917. doi:10.1089/hum.1998.9.131909

Gama-Norton, L., Botezatu, L., Herrmann, S., Schweizer, M., Alves, P. M., Hauser, H., et al. (2011). Lentivirus Production Is Influenced by SV40 Large T-Antigen and Chromosomal Integration of the Vector in HEK293 Cells. Hum. Gene Ther. 22, 1269-1279. doi:10.1089/hum.2010.143

Ghani, K., Boivin-Welch, M., Roy, S., Dakiw-Piaceski, A., Barbier, M., Pope, E., et al. (2019). Generation of High-Titer Self-Inactivated $\gamma$-Retroviral Vector Producer Cells. Mol. Ther. - Methods Clin. Dev. 14, 90-99. doi:10.1016/ j.omtm.2019.05.013

Ghani, K., Cottin, S., Kamen, A., and Caruso, M. (2007). Generation of a HighTiter Packaging Cell Line for the Production of Retroviral Vectors in Suspension and Serum-free media. Gene Ther. 14, 1705-1711. doi:10.1038/ sj.gt.3303039

Goh, J. B., and Ng, S. K. (2017). Impact of Host Cell Line Choice on Glycan Profile. Crit. Rev. Biotechnol. 38, 851-867. doi:10.1080/07388551.2017.1416577

Graham, F. L., Russell, W. C., Smiley, J., and Nairn, R. (1977). Characteristics of a Human Cell Line Transformed by DNA from Human Adenovirus Type 5. J. Gen. Virol. 36, 59-72. doi:10.1099/0022-1317-36-1-59

Grieger, J. C., Soltys, S. M., and Samulski, R. J. (2016). Production of Recombinant Adeno-Associated Virus Vectors Using Suspension HEK293 Cells and Continuous Harvest of Vector from the Culture Media for GMP FIX and FLT1 Clinical Vector. Mol. Ther. 24, 287-297. doi:10.1038/mt.2015.187

Hacker, D. L., De Jesus, M., and Wurm, F. M. (2009). 25 Years of Recombinant Proteins from Reactor-Grown Cells - where Do We Go from Here? Biotechnol. Adv. 27, 1023-1027. doi:10.1016/j.biotechadv.2009.05.008

Hehir, K. M., Armentano, D., Cardoza, L. M., Choquette, T. L., Berthelette, P. B., White, G. A., et al. (1996). Molecular Characterization of ReplicationCompetent Variants of Adenovirus Vectors and Genome Modifications to Prevent Their Occurrence. J. Virol. 70, 8459-8467. doi:10.1128/jvi.70.12.84598467.1996

Kannicht, C., Kohla, G., Tiemeyer, M., Walter, O., and Sandberg, H. (2015). A New Recombinant Factor VIII: from Genetics To clinical Use. Dddt 9, 3817-3819. doi: $10.2147 /$ dddt.s85608

Kannicht, C., Ramström, M., Kohla, G., Tiemeyer, M., Casademunt, E., Walter, O., et al. (2013). Characterisation of the post-translational Modifications of a Novel, Human Cell Line-Derived Recombinant Human Factor VIII. Thromb. Res. 131, 78-88. doi:10.1016/j.thromres.2012.09.011

Kunert, R., and Reinhart, D. (2016). Advances in Recombinant Antibody Manufacturing. Appl. Microbiol. Biotechnol. 100, 3451-3461. doi:10.1007/ s00253-016-7388-9

Lai, T., Yang, Y., and Ng, S. (2013). Advances in Mammalian Cell Line Development Technologies for Recombinant Protein Production. Pharmaceuticals 6, 579-603. doi:10.3390/ph6050579

Lalonde, M.-E., and Durocher, Y. (2017). Therapeutic Glycoprotein Production in Mammalian Cells. J. Biotechnol. 251, 128-140. doi:10.1016/ j.jbiotec.2017.04.028
Lapteva, L., Purohit-Sheth, T., Serabian, M., and Puri, R. K. (2020). Clinical Development of Gene Therapies: The First Three Decades and Counting. Mol. Ther. - Methods Clin. Dev. 19, 387-397. doi:10.1016/ j.omtm.2020.10.004

Lochmüller, H., Jani, A., Huard, J., Prescott, S., Simoneau, M., Massie, B., et al. (1994). Emergence of Early Region 1-Containing Replication-Competent Adenovirus in Stocks of Replication-Defective Adenovirus Recombinants $(\Delta \mathrm{E} 1+\Delta \mathrm{E} 3)$ during Multiple Passages in 293 Cells. Hum. Gene Ther. 5, 1485-1491. doi:10.1089/hum.1994.5.12-1485

Lock, M., Alvira, M., Vandenberghe, L. H., Samanta, A., Toelen, J., Debyser, Z., et al. (2010). Rapid, Simple, and Versatile Manufacturing of Recombinant Adeno-Associated Viral Vectors at Scale. Hum. Gene Ther. 21, 1259-1271. doi:10.1089/hum.2010.055

Loew, R., Meyer, Y., Kuehlcke, K., Gama-Norton, L., Wirth, D., Hauser, H., et al. (2010). A New PG13-Based Packaging Cell Line for Stable Production of Clinical-Grade Self-Inactivating $\gamma$-retroviral Vectors Using Targeted Integration. Gene Ther. 17, 272-280. doi:10.1038/gt.2009.134

Maetzig, T., Galla, M., Baum, C., and Schambach, A. (2011). Gammaretroviral Vectors: Biology, Technology and Application. Viruses 3, 677-713. doi:10.3390/ v3060677

Manceur, A. P., Kim, H., Misic, V., Andreev, N., Dorion-Thibaudeau, J., Lanthier, S., et al. (2017). Scalable Lentiviral Vector Production Using Stable HEK293SF Producer Cell Lines. Hum. Gene Ther. Methods 28, 330-339. doi:10.1089/ hgtb.2017.086

McCarron, A., Donnelley, M., McIntyre, C., and Parsons, D. (2016). Challenges of Up-Scaling Lentivirus Production and Processing. J. Biotechnol. 240, 23-30. doi:10.1016/j.jbiotec.2016.10.016

Mendonça, S. A., Lorincz, R., Boucher, P., and Curiel, D. T. (2021). Adenoviral Vector Vaccine Platforms in the SARS-CoV-2 Pandemic. Npj Vaccin. 6, 97. doi:10.1038/s41541-021-00356-x

Merten, O.-W., Hebben, M., and Bovolenta, C. (2016). Production of Lentiviral Vectors. Mol. Ther. - Methods Clin. Dev. 3, 16017. doi:10.1038/mtm.2016.17

Mietzsch, M., Casteleyn, V., Weger, S., Zolotukhin, S., and Heilbronn, R. (2015). OneBac 2.0:Sf9 Cell Lines for Production of AAV5 Vectors with Enhanced Infectivity and Minimal Encapsidation of Foreign DNA. Hum. Gene Ther. 26, 688-697. doi:10.1089/hum.2015.050

Mietzsch, M., Grasse, S., Zurawski, C., Weger, S., Bennett, A., Agbandje-McKenna, M., et al. (2014). OneBac: Platform for Scalable and High-Titer Production of Adeno-Associated Virus Serotype 1-12 Vectors for Gene Therapy. Hum. Gene Ther. 25, 212-222. doi:10.1089/hum.2013.184

Mietzsch, M., Hering, H., Hammer, E.-M., Agbandje-McKenna, M., Zolotukhin, S., and Heilbronn, R. (2017). OneBac 2.0:Sf9 Cell Lines for Production of AAV1, AAV2, and AAV8 Vectors with Minimal Encapsidation of Foreign DNA. Hum. Gene Ther. Methods 28, 15-22. doi:10.1089/hgtb.2016.164

Milone, M. C., and O'Doherty, U. (2018). Clinical Use of Lentiviral Vectors. Leukemia 32, 1529-1541. doi:10.1038/s41375-018-0106-0

Mitchell, R. S., Beitzel, B. F., Schroder, A. R. W., Shinn, P., Chen, H., Berry, C. C., et al. (2004). Retroviral DNA Integration: ASLV, HIV, and MLV Show Distinct Target Site Preferences. Plos Biol. 2, e234. doi:10.1371/journal.pbio.0020234

Modlich, U., Bohne, J., Schmidt, M., von Kalle, C., Knöss, S., Schambach, A., et al. (2006). Cell-culture Assays Reveal the Importance of Retroviral Vector Design for Insertional Genotoxicity. Blood 108, 2545-2553. doi:10.1182/blood-200508-024976

Mullard, A. (2016). 2015 FDA Drug Approvals. Nat. Rev. Drug Discov. 15, 73-76. doi:10.1038/nrd.2016.15

Mullard, A. (2017). 2016 FDA Drug Approvals. Nat. Rev. Drug Discov. 16, 73-76. doi:10.1038/nrd.2017.14

Mullard, A. (2018). 2017 FDA Drug Approvals. Nat. Rev. Drug Discov. 17, 81-85. doi:10.1038/nrd.2018.4

Mullard, A. (2019). 2018 FDA Drug Approvals. Nat. Rev. Drug Discov. 18, 85-89. doi:10.1038/d41573-019-00014-x

Mullard, A. (2020). 2019 FDA Drug Approvals. Nat. Rev. Drug Discov. 19, 79-84. doi:10.1038/d41573-020-00001-7

Mullard, A. (2021). 2020 FDA Drug Approvals. Nat. Rev. Drug Discov. 20, 85-90. doi:10.1038/d41573-021-00002-0

Naso, M. F., Tomkowicz, B., Perry, W. L., and Strohl, W. R. (2017). AdenoAssociated Virus (AAV) as a Vector for Gene Therapy. Biodrugs 31, 317-334. doi:10.1007/s40259-017-0234-5 
Nguyen, N. T. B., Lin, J., Tay, S. J., MariatiYeo, J., Yeo, J., Nguyen-Khuong, T., et al. (2021). Multiplexed Engineering Glycosyltransferase Genes in CHO Cells via Targeted Integration for Producing Antibodies with Diverse Complex-type N-Glycans. Sci. Rep. 11, 12969. doi:10.1038/s41598-021-92320-x

Pham, P. L., Kamen, A., and Durocher, Y. (2006). Large-Scale Transfection of Mammalian Cells for the Fast Production of Recombinant Protein. Mb 34, 225-238. doi:10.1385/mb:34:2:225

Raper, S. E., Chirmule, N., Lee, F. S., Wivel, N. A., Bagg, A., Gao, G.-p., et al. (2003). Fatal Systemic Inflammatory Response Syndrome in a Ornithine Transcarbamylase Deficient Patient Following Adenoviral Gene Transfer. Mol. Genet. Metab. 80, 148-158. doi:10.1016/j.ymgme.2003.08.016

Richardson, W. D., and Westphal, H. (1984). Requirement for Either Early Region 1a or Early Region 1b Adenovirus Gene Products in the Helper Effect for AdenoAssociated Virus. J. Virol. 51, 404-410. doi:10.1128/jvi.51.2.404-410.1984

Rittié, L., Athanasopoulos, T., Calero-Garcia, M., Davies, M. L., Dow, D. J., Howe, S. J., et al. (2019). The Landscape of Early Clinical Gene Therapies outside of Oncology. Mol. Ther. 27, 1706-1717. doi:10.1016/j.ymthe.2019.09.002

Rodrigues, A., Alves, P. M., and Coroadinh, A. (2011). Production of Retroviral and Lentiviral Gene Therapy Vectors: Challenges in the Manufacturing of Lipid Enveloped Virus. Ke Xu, IntechOpen. Available from: https://www.intechopen. com/chapters/16776. doi:10.5772/18615

Rout-Pitt, N., McCarron, A., McIntyre, C., Parsons, D., and Donnelley, M. (2018). Large-scale Production of Lentiviral Vectors Using Multilayer Cell Factories. J. Biol. Methods 5, e90. doi:10.14440/jbm.2018.236

Rumachik, N. G., Malaker, S. A., Poweleit, N., Maynard, L. H., Adams, C. M., Leib, R. D., et al. (2020). Methods Matter: Standard Production Platforms for Recombinant AAV Produce Chemically and Functionally Distinct Vectors. Mol. Ther. - Methods Clin. Dev. 18, 98-118. doi:10.1016/ j.omtm.2020.05.018

Sandberg, H., Kannicht, C., Stenlund, P., Dadaian, M., Oswaldsson, U., Cordula, C., et al. (2012). Functional Characteristics of the Novel, Human-Derived Recombinant FVIII Protein Product, Human-Cl rhFVIII. Thromb. Res. 130, 808-817. doi:10.1016/j.thromres.2012.08.311

Schiedner, G., Hertel, S., and Kochanek, S. (2000). Efficient Transformation of Primary Human Amniocytes by E1 Functions of Ad5: Generation of New Cell Lines for Adenoviral Vector Production. Hum. Gene Ther. 11, 2105-2116. doi:10.1089/104303400750001417

Segura, M. M., Garnier, A., Durocher, Y., Coelho, H., and Kamen, A. (2007). Production of Lentiviral Vectors by Large-Scale Transient Transfection of Suspension Cultures and Affinity Chromatography Purification. Biotechnol. Bioeng. 98, 789-799. doi:10.1002/bit.21467

Stewart, H. J., Leroux-Carlucci, M. A., Sion, C. J. M., Mitrophanous, K. A., and Radcliffe, P. A. (2009). Development of Inducible EIAV-Based Lentiviral Vector Packaging and Producer Cell Lines. Gene Ther. 16, 805-814. doi:10.1038/gt.2009.20

Strobel, B., Zuckschwerdt, K., Zimmermann, G., Mayer, C., Eytner, R., Rechtsteiner, P., et al. (2019). Standardized, Scalable, and Timely Flexible Adeno-Associated Virus Vector Production Using Frozen High-Density HEK-293 Cell Stocks and CELLdiscs. Hum. Gene Ther. Methods 30, 23-33. doi:10.1089/hgtb.2018.228

Tejwani, V., Andersen, M. R., Nam, J. H., and Sharfstein, S. T. (2018). Glycoengineering in CHO Cells: Advances in Systems Biology. Biotechnol. J. 13, 1700234. doi:10.1002/biot.201700234

Tomás, H. A., Rodrigues, A. F., Carrondo, M. J. T., and Coroadinha, A. S. (2018). LentiPro26: Novel Stable Cell Lines for Constitutive Lentiviral Vector Production. Sci. Rep. 8, 5271. doi:10.1038/s41598-018-23593-y

Tratschin, J. D., West, M. H., Sandbank, T., and Carter, B. J. (1984). A Human Parvovirus, Adeno-Associated Virus, as a Eucaryotic Vector: Transient Expression and Encapsidation of the Procaryotic Gene for Chloramphenicol Acetyltransferase. Mol. Cel. Biol. 4, 2072-2081. doi:10.1128/mcb.4.10.2072

Tripodi, L., Vitale, M., Cerullo, V., and Pastore, L. (2021). Oncolytic Adenoviruses for Cancer Therapy. Ijms 22, 2517. doi:10.3390/ijms22052517

Urabe, M., Ding, C., and Kotin, R. M. (2002). Insect Cells as a Factory to Produce Adeno-Associated Virus Type 2 Vectors. Hum. Gene Ther. 13, 1935-1943. doi:10.1089/10430340260355347
U.S. Food and Drug Administration (2021b). ABECMA. Available at: https://www. fda.gov/vaccines-blood-biologics/abecma-idecabtagene-vicleucel (Accessed November 10, 2021).

U.S. Food and Drug Administration (2021a). BREYANZI. Available at: https:// www.fda.gov/vaccines-blood-biologics/cellular-gene-therapy-products/ breyanzi-lisocabtagene-maraleucel (Accessed November 10, 2021).

U.S. Food and Drug Administration (2017c). KYMRIAH. Available at: https:// www.fda.gov/vaccines-blood-biologics/cellular-gene-therapy-products/ kymriah-tisagenlecleucel (Accessed November 10, 2021).

U.S. Food and Drug Administration (2017a). LUXTURNA. Available at: https:// www.fda.gov/vaccines-blood-biologics/cellular-gene-therapy-products/ luxturna (Accessed November 10, 2021).

U.S. Food and Drug Administration (2015). NUWIQ. Available at: https://www. fda.gov/vaccines-blood-biologics/approved-blood-products/nuwiq (Accessed November 10, 2021).

U.S. Food and Drug Administration (2017b). YESCARTA. Available at: https:// www.fda.gov/vaccines-blood-biologics/cellular-gene-therapy-products/ yescarta-axicabtagene-ciloleucel (Accessed November 10, 2021).

U.S. Food and Drug Administration (2019). ZOLGENSMA. Available at: https://www. fda.gov/vaccines-blood-biologics/zolgensma (Accessed November 10, 2021).

van der Loo, J. C. M., Swaney, W. P., Grassman, E., Terwilliger, A., Higashimoto, T., Schambach, A., et al. (2012). Scale-up and Manufacturing of Clinical-Grade Self-Inactivating $\gamma$-retroviral Vectors by Transient Transfection. Gene Ther. 19, 246-254. doi:10.1038/gt.2011.102

van Doremalen, N., Lambe, T., Spencer, A., Belij-Rammerstorfer, S., Purushotham, J. N., Port, J. R., et al. (2020). ChAdOx1 nCoV-19 Vaccine Prevents SARS-CoV2 Pneumonia in Rhesus Macaques. Nature 586, 578-582. doi:10.1038/s41586020-2608-y

Weiss, R. A. (1996). Retrovirus Classification and Cell Interactions. J. Antimicrob. Chemother. 37, 1-11. doi:10.1093/jac/37.suppl_b.1

Wurm, F., and Bernard, A. (1999). Large-scale Transient Expression in Mammalian Cells for Recombinant Protein Production. Curr. Opin. Biotechnol. 10, 156-159. doi:10.1016/s0958-1669(99)80027-5

Yu, D. Y., Lee, S. Y., and Lee, G. M. (2018). Glutamine Synthetase Gene KnockoutHuman Embryonic Kidney 293E Cells for Stable Production of Monoclonal Antibodies. Biotechnol. Bioeng. 115, 1367-1372. doi:10.1002/bit.26552

Yu, S. F., von Ruden, T., Kantoff, P. W., Garber, C., Seiberg, M., Ruther, U., et al. (1986). Self-inactivating Retroviral Vectors Designed for Transfer of Whole Genes into Mammalian Cells. Proc. Natl. Acad. Sci. 83, 3194-3198. doi:10.1073/ pnas.83.10.3194

Yuan, J., W. Xu, W., Jiang, S., Yu, H., and Fai Poon, H. (2018). The Scattered Twelve Tribes of HEK293. Biomed. Pharmacol. J. 11, 621-623. doi:10.13005/ bpj/1414

Zhu, F.-C., Li, Y.-H., Guan, X.-H., Hou, L.-H., Wang, W.-J., Li, J.-X., et al. (2020). Safety, Tolerability, and Immunogenicity of a Recombinant Adenovirus Type-5 Vectored COVID-19 Vaccine: a Dose-Escalation, Open-Label, Nonrandomised, First-In-Human Trial. The Lancet 395, 1845-1854. doi:10.1016/ s0140-6736(20)31208-3

Conflict of Interest: The authors declare that the research was conducted in the absence of any commercial or financial relationships that could be construed as a potential conflict of interest.

Publisher's Note: All claims expressed in this article are solely those of the authors and do not necessarily represent those of their affiliated organizations, or those of the publisher, the editors and the reviewers. Any product that may be evaluated in this article, or claim that may be made by its manufacturer, is not guaranteed or endorsed by the publisher.

Copyright $\odot 2021$ Tan, Chin, Lim and Ng. This is an open-access article distributed under the terms of the Creative Commons Attribution License (CC BY). The use, distribution or reproduction in other forums is permitted, provided the original author(s) and the copyright owner(s) are credited and that the original publication in this journal is cited, in accordance with accepted academic practice. No use, distribution or reproduction is permitted which does not comply with these terms. 